PETIR: Jurnal Pengkajian dan Penerapan Teknik Informatika Vol. 13, No. 1, Maret 2020, P-ISSN 1978-9262, E-ISSN 2655-5018 DOI: https://doi.org/10.33322/petir.v13i1.925

\title{
Penerapan Metode K-Means Dan C4.5 Untuk Prediksi Penderita Diabetes
}

\author{
Andika Prasatya $^{1}$; Riki Ruli A Siregar ${ }^{2}$; Rakhmat Arianto ${ }^{3}$ \\ ${ }^{1,2}$ Program Studi Teknik Informatika, Institut Teknologi PLN \\ ${ }^{3}$ Politeknik Negeri Malang \\ andika1531220@itpln.ac.id \\ ${ }^{2}$ riki.ruli@itpln.ac.id \\ 3ari87anto@gmail.com
}

\begin{abstract}
The purpose of this study is to predict HbAlc in diabetics. The obstacles behind the prediction of $\mathrm{HbAlc}$ is the limitations in the laboratory to provide services for diabetics regarding HbAl checkup. HbAlc prediction is made by a combination of K-Means and C4.5 methods. K-Means is used to classify continuous data. From the results of the K-Means classification will be used by C4.5 to create a rule (decision tree). The prediction results obtained will be carried out as a validation process to determine the level of accuracy by using K-Fold Cross-Validation. The accuracy value obtained is $72 \%$. The resulting benefit from the prediction of HbAlc can be used as an alternative solution to overcome limitations in the laboratory in terms of HbAlc check-up servicing and the results of HbAlc prediction can also be used as a recommendation by doctor in determining the medical decision for diabetics.
\end{abstract}

Keywords: Combinations, Predictions, HbAlc, Validation, Diabetics

\begin{abstract}
ABSTRAK
Tujuan dari penelitian ini yaitu melakukan prediksi HbAlc pada penderita diabetes. Adapun kendala yang melatarbelakangi prediksi HbAlc adalah adanya keterbatasan pada laboratorium untuk memberikan pelayanan kepada penderita diabetes dalam hal pemeriksaan HbAlc. Prediksi HbAlc dilakukan dengan kombinasi metode K-Means dengan C4.5. K-Means digunakan untuk mengelompokkan data yang bersifat kontinu. Dari hasil pengelompokan K-Means akan digunakan oleh C4.5 untuk membuat rule (pohon keputusan). Hasil prediksi yang didapatkan akan dilakukan proses validasi untuk mengetahui tingkat keakurasian dengan menggunakan K-Fold Cross Validation. Nilai akurasi yang didapatkan sebesar 72\%. Manfaat yang dihasilkan dari prediksi HbAlc adalah dapat digunakan sebagai alternatif solusi untuk mengatasi keterbatasan pada laboratorium dalam hal pelayanan pemeriksaan HbAlc dan hasil prediksi HbAlc dapat juga digunakan sebagai rekomendasi oleh dokter dalam menentukan keputusan medis pada penderita diabetes.
\end{abstract}

Kata kunci: Kombinasi, Prediksi, HbAlc, Validasi, Diabetes 
PETIR: Jurnal Pengkajian dan Penerapan Teknik Informatika Vol. 13, No. 1, Maret 2020, P-ISSN 1978-9262, E-ISSN 2655-5018 DOI: https://doi.org/10.33322/petir.v13i1.925

\section{PENDAHULUAN}

Hasil survei mengenai masyarakat yang menderita diabetes, didapatkan sekitar 30\% penderita diabetes tidak mengetahui penyakitnya dan penderita diabetes tersebut baru mengetahuinya setelah mendapatkan hasil diagnosis keluar dari hasil tes laboratorium, bahkan sekitar 25\% telah terkena komplikasi mikrovaskular [1]. Komplikasi mikrovaskular yakni komplikasi yang dapat menyebabkan kerusakan pada mata, ginjal, indra perasa, dan lain-lain yang terjadi pada pembuluh darah kecil. Diprediksi ada 439 juta orang yang pada tahun 2030 akan menderita penyakit diabetes. Sehingga penyakit diabetes merupakan persoalan kesehatan di semua negara [2].

Hemoglobin yang berhubungan dengan glukosa disebut dengan HbAlc (hemoglobin A1c) atau glycated hemoglobin. Glukosa akan saling mengikat dengan hemoglobin yang ada didalam sel darah merah yang terjadi didalam darah. HbA1c ini nanti digunakan dokter untuk memberikan keputusan yang sesuai bagi penderita diabetes. Keputusan tersebut mengandung obat yang akan diberikan, larangan yang diberikan untuk penderita, berapa kali harus menemui dokter untuk mengontrol diabetes penderita dan lain-lain. Usulan diperlukan prediksi HbAlc untuk mengatasi keterbatasan dalam pemberian pelayanan tes $H b A l c$ pada laboratorium bagi penderita diabetes.

Adapun penelitian yang berhubungan dengan bidang medis yang dimana pada penelitian tersebut, membandingkan algoritma Decision Tree C4.5 dengan algoritma Naive Bayes. Hasil akurasi yang diperoleh yaitu algoritma Decision Tree C4.5 sebesar 90\%. Untuk algoritma Naive Bayes sebesar $89.58 \%$ [3]. Dan terdapat juga hasil penelitian mengenai pengelompokan data yang dimana penelitian tersebut membandingkan metode Clustering K-Means dengan Agglomerative Hierarchical Clustering (AHC). Hasil yang didapatkan dari penelitian tersebut menunjukkan bahwa metode Clustering $\mathrm{K}$-Means lebih baik dalam mengelompokkan data dibandingkan dengan metode Agglomerative Hierarchical Clustering (AHC) [4].

Sehingga dapat disimpulkan dalam penelitian ini akan menerapkan metode klasifikasi C4.5 untuk memprediksi $H b A l C$ pasien penderita diabetes. Dan untuk pengelompokan menggunakan metode clustering K-Means. Pengelompokan dilakukan terlebih dahulu sebelum melakukan proses metode $C 4.5$.

\section{METODE PENELITIAN}

Tahapan-tahapan yang digunakan dalam proses data mining adalah CRISP-DM (CrossIndustry Standard Process Model for Data Mining). Adapun gambaran tahapan diagram CRISP-DM sebagai berikut (gambar 1):

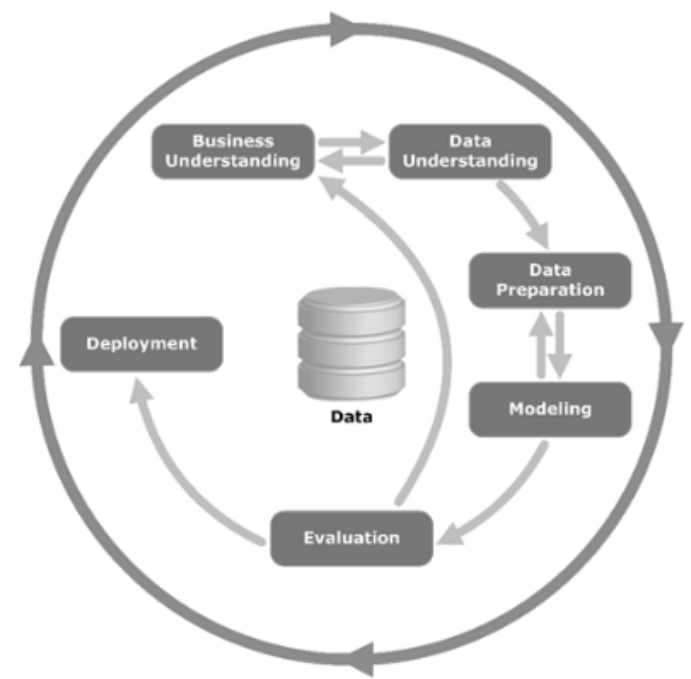

Gambar 1. Diagram CRISP-DM [5] 
PETIR: Jurnal Pengkajian dan Penerapan Teknik Informatika Vol. 13, No. 1, Maret 2020, P-ISSN 1978-9262, E-ISSN 2655-5018 DOI: https://doi.org/10.33322/petir.v13i1.925

\subsection{Business Understanding}

Menjelaskan bagaimana bisnis atau sistem yang sedang berjalan yang berkaitan dengan penelitian yang dilakukan. Adapun penelitian pada tahapan business understanding sebagai berikut:

a. Menentukan Tujuan Bisnis (Determine Business Objectives) Untuk mengenali proses diagnosis diabetes pada pasien dan mengetahui proses penanganan pasien penderita diabetes.

b. Menilai Situasi (Assess the Situation) Adapun diagram alur proses diagnosis diabetes pada pasien dan diagram alur perawatan pasien yang telah terkena diabetes [6].

c. Menentukan Tujuan Data Mining (Determine the Data Mining Goals)

Tujuan data mining adalah untuk memprediksikan hasil $\mathrm{HbAlc}$.

\subsection{Data Understanding}

Memahami data yang akan digunakan dalam penelitian. Adapun penelitian pada tahapan data understanding sebagai berikut:

a. Mengumpulkan Data Awal (Collect the Initial Data)

Data yang dikumpulkan dari dataset yang diambil dari UCI Machine Learning yang di publikasi kan dari penelitian sebelumnya yang berjudul Impact of HbAlc Measurement on Hospital Readmission Rates: Analysis of 70,000 Clinical Database [7].

b. Mendeskripsikan Data (Describe the Data) Mendeskripsi setiap atribut-atribut yang terdapat pada dataset yang digunakan.

c. Mengeksplorasi Data (Explore the Data)

Mendeskripsikan tipe nilai dan jenis nilai pada tiap atribut pada dataset yang digunakan.

d. Memverifikasi Kualitas Data (Verify Data Quality)

Mendeskripsikan total nilai kosong (missing) pada tiap atribut pada dataset yang digunakan.

\subsection{Data Preparation}

a. Mendeskripsikan Data Set (Data Set Description)

Deskripsi data sesuai pada 2.2. bagian b. mendeskripsikan data.

b. Memilih Data (Select Data)

Pada penelitian lebih bertujuan pada memprediksi nilai HbA1c. Untuk hal tersebut dari atribut-atribut data pada dataset hanya akan di digunakan beberapa yang dibutuhkan dalam proses prediksi HbA1c. Adapun atribut-atribut data yang digunakan untuk metode $K$ Means dan $C 4.5$ sebagai berikut:

Tabel 1. Atribut Metode K-Means

\begin{tabular}{|c|l|}
\hline No & \multicolumn{1}{|c|}{ Nama Atribut } \\
\hline 1 & Time in Hospital \\
\hline 2 & Numbers of Lab Procedures \\
\hline 3 & Numbers of Procedures \\
\hline 4 & Number of Diagnoses \\
\hline
\end{tabular}

Tabel 2. Atribut Metode C4.5

\begin{tabular}{|c|l|}
\hline No & \multicolumn{1}{|c|}{ Nama Atribut } \\
\hline 1 & Gender \\
\hline 2 & Age \\
\hline 3 & Admission Type \\
\hline 4 & Discharge Disposition \\
\hline
\end{tabular}


PETIR: Jurnal Pengkajian dan Penerapan Teknik Informatika Vol. 13, No. 1, Maret 2020, P-ISSN 1978-9262, E-ISSN 2655-5018

\begin{tabular}{|c|l|}
\hline No & \multicolumn{1}{|c|}{ Nama Atribut } \\
\hline 5 & Admission Source \\
\hline 6 & Diagnosis 1 \\
\hline 7 & Diagnosis 2 \\
\hline 8 & Diagnosis 3 \\
\hline 9 & Alc test result \\
\hline 10 & Change of Medications \\
\hline 11 & Diabetes Medications \\
\hline 12 & Readmitted \\
\hline
\end{tabular}

Atribut hasil proses K-Means akan digunakan pada proses C4.5. Pada tabel 1 dan 2 menjelaskan atribut nilai yang akan digunakan langsung berdasarkan dari dataset yang digunakan.

c. Membersihkan Data (Clean Data)

Dari hasil atribut-atribut yang telah dipilih, akan pembersihan pada data yang terdapat pada atribut ini. Dalam penelitian ini akan menghapus data dari atribut A1c Test Result yang bernilai None. Tujuan menghapus nilai adalah agar proses klasifikasi dengan metode $\mathrm{C} 4.5$ hasil yang dikeluarkan lebih tepat dan hasil prediksi tidak terdapat nilai none (tidak diketahui).

Adapun jumlah data dalam data set tersebut berjumlah 101767 data. Setelah dilakukan pembersihan data, data yang tersisa berjumlah 17019 .

\subsection{Modeling}

Modeling pada tahapan ini menjelaskan bagaimana pemodelan yang akan diterapkan dalam data mining. Adapun gambaran langkah-langkah pemodelan data mining sebagai berikut:

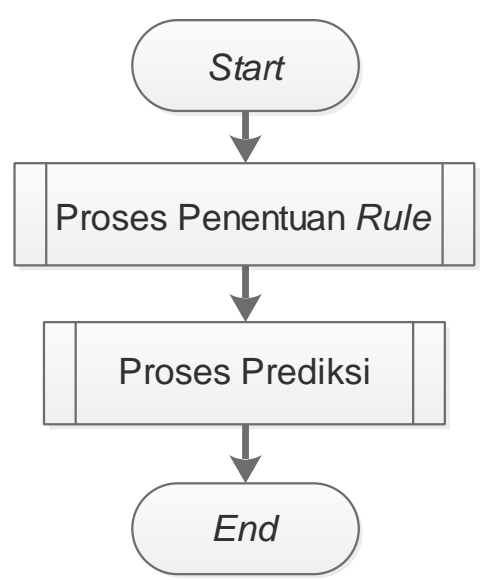

Gambar 2. Alur Pemodelan Utama 
PETIR: Jurnal Pengkajian dan Penerapan Teknik Informatika Vol. 13, No. 1, Maret 2020, P-ISSN 1978-9262, E-ISSN 2655-5018 DOI: https://doi.org/10.33322/petir.v13i1.925

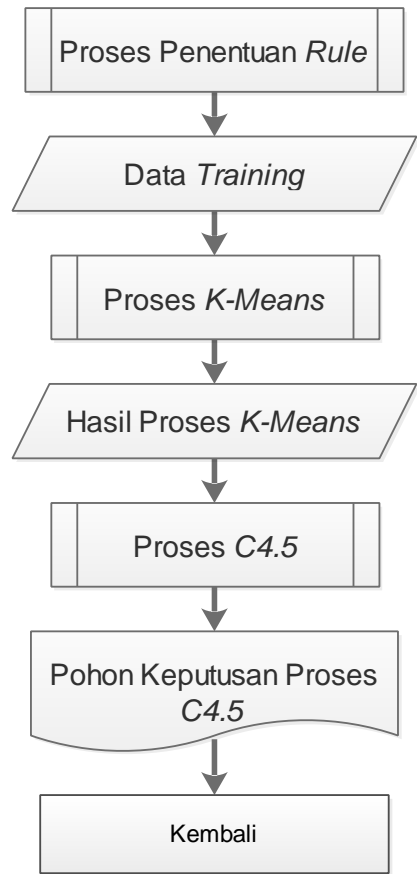

Gambar 3. Alur Pemodelan Pohon Keputusan (Rule) Prediksi HbA1c

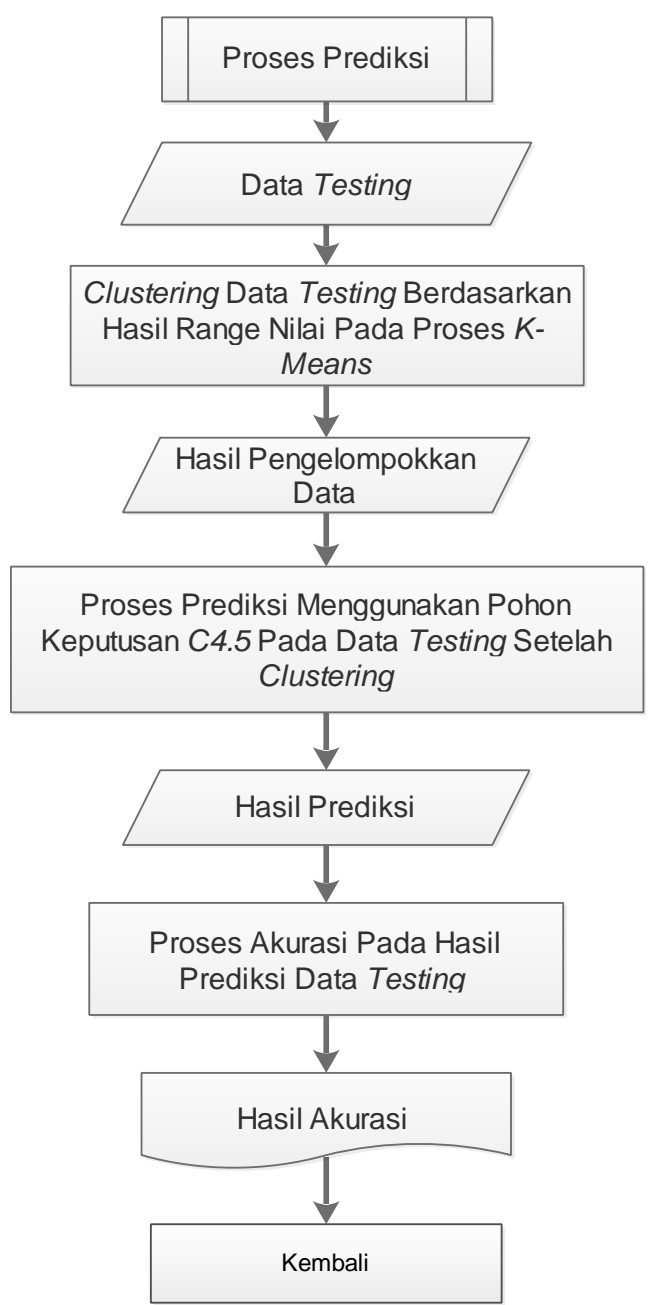

Gambar 4. Alur Pemodelan Prediksi HbA1c 
PETIR: Jurnal Pengkajian dan Penerapan Teknik Informatika Vol. 13, No. 1, Maret 2020, P-ISSN 1978-9262, E-ISSN 2655-5018 DOI: https://doi.org/10.33322/petir.v13i1.925

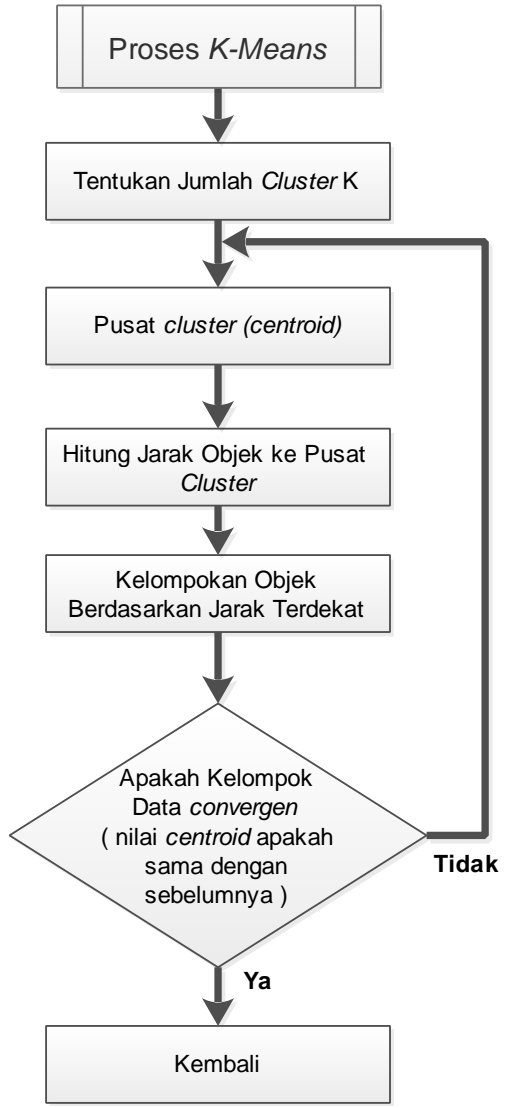

Gambar 5. Diagram Tahapan K-Means [8]

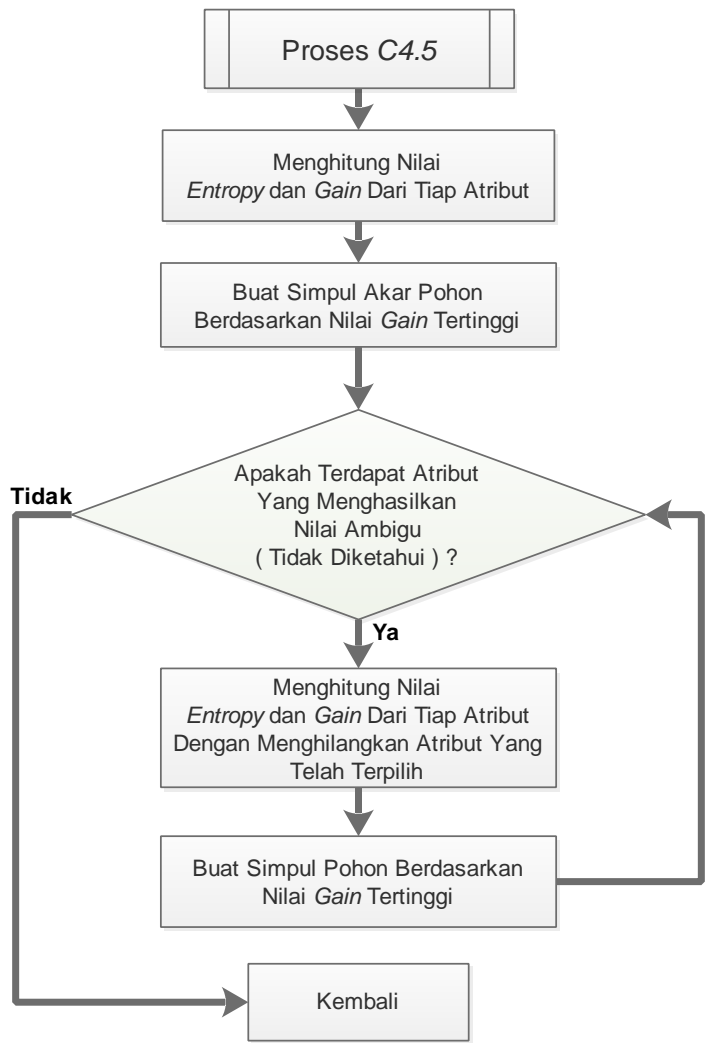

Gambar 6. Diagram Tahapan C4.5 [9] 
Selanjutnya adalah rumus yang akan digunakan dari tiap metode sebagai berikut :

a. Metode K-Means

1. Rumus Mencari Jarak Objek Centroid (Euclidean Distance) [8].

$$
d(x, y)=\sqrt{\sum_{i=1}^{n}\left(x_{i-} y_{i}\right)^{2}}
$$

Keterangan:

$\mathrm{d}=$ jarak antara $\mathrm{x}$ dan $\mathrm{y}$

$\mathrm{x}=$ data pusat klaster

$\mathrm{y}=$ data pada atribut

$\mathrm{i}=$ setiap data

$\mathrm{n}=$ jumlah data

$\mathrm{xi}=$ data pada pusat klaster ke $\mathrm{i}$

$\mathrm{yi}=$ data pada setiap data ke $\mathrm{i}$

2. Rumus Menentukan Centroid Baru [8].

$$
C_{i}=\frac{\sum_{i=1}^{n} x_{i} \in s_{i}}{n}
$$

Keterangan:

$\mathrm{Ci}=$ centroid baru ke $\mathrm{i}$

si $=$ objek ke $\mathrm{i}$

$\mathrm{xi}=$ nilai pada objek ke $\mathrm{i}$

$\mathrm{n}=$ jumlah data pada tiap kelompok

b. Metode $C 4.5$

1. Rumus Entropy [10]

$$
\operatorname{Entropy}(S)=\sum_{i=1}^{n}-p i * \log 2 p i
$$

Keterangan:

$\mathrm{S}=$ Himpunan Kasus

$\mathrm{n}=$ jumlah partisi $\mathrm{S}$

pi = proporsi dari Si terhadap $\mathrm{S}$

2. Rumus Gain [10]

$$
\operatorname{Gain}(S, A)=\operatorname{Entropy}(S)-\sum_{i=1}^{n} \frac{\left|S_{i}\right|}{|S|} * \operatorname{Entropy}\left(S_{i}\right)
$$

Keterangan:

$\mathrm{S}=$ Himpunan Kasus

$\mathrm{A}=$ Atribut

$\mathrm{n}=$ jumlah partisi atribut $\mathrm{A}$

$|\mathrm{Si}|=$ jumlah kasus pada partisi ke-i

$|\mathrm{S}|=$ jumlah kasus dalam $\mathrm{S}$ 
PETIR: Jurnal Pengkajian dan Penerapan Teknik Informatika

Adapun penerapan proses metode $K$-Means dan $C 4.5$ sebagai berikut:

A. Proses $K$-Means

Pada proses $K$-Means hanya akan dijelaskan sebagian. Contoh proses yang dijelaskan disini adalah proses $K$-Means pada atribut Time In Hospital. Dalam perhitungan ini menggunakan 10 data sampel dari dataset yang digunakan. Perhitungan ini menetapkan jumlah kelompok (cluster) berjumlah 3. Penentuan jumlah kelompok berdasarkan kebutuhan. Adapun langkah sebagai berikut:

1. Tentukan Nilai Centroid Awal (Random)

Tabel 3. Nilai Centroid Loop-1 Time In Hospital

\begin{tabular}{|c|c|c|}
\hline Perulangan & Nama Centroid & Nilai Centroid \\
\hline \multirow{3}{*}{ Loop - 1} & Centroid 1 & 1 \\
\cline { 2 - 3 } & Centroid 2 & 14 \\
\cline { 2 - 3 } & Centroid 3 & 8 \\
\hline
\end{tabular}

Pada tabel 3 merupakan penentuan nilai centroid awal atribut time in hospital secara random.

2. Perhitungan Euclidean Distance setiap centroid pada tabel 3.

Tabel 4. Nilai Euclidean Distance Centroid 1 Loop-1 Time In Hospital

\begin{tabular}{|c|c|c|}
\hline No & Perhitungan & $\begin{array}{c}\text { Hasil Euclidean Distance } \\
\text { Centroid 1 }\end{array}$ \\
\hline 1 & $\sqrt{(1-1)^{2}}$ & 0 \\
\hline 2 & $\sqrt{(3-1)^{2}}$ & 2 \\
\hline 3 & $\sqrt{(14-1)^{2}}$ & 13 \\
\hline 4 & $\sqrt{(2-1)^{2}}$ & 1 \\
\hline 5 & $\sqrt{(14-1)^{2}}$ & 13 \\
\hline 6 & $\sqrt{(9-1)^{2}}$ & 12 \\
\hline 7 & $\sqrt{(13-1)^{2}}$ & 4 \\
\hline 8 & $\sqrt{(5-1)^{2}}$ & 7 \\
\hline 9 & $\sqrt{(8-1)^{2}}$ & 13 \\
\hline 10 & $\sqrt{(14-1)^{2}}$ & 12 \\
\hline
\end{tabular}

Pada tabel 4 merupakan hasil perhitungan Euclidean Distance Centroid 1 Loop1 Time In Hospital yang dimana nilai yang digunakan pada perhitungan ini berdasarkan nilai dari dataset atribut time in hospital dan nilai centroid 1 pada tabel 3 dan menggunakan rumus 1. Untuk kolom hasil Euclidean Distance Centroid 1 merupakan hasil dari perhitungan dari kolom perhitungan.

Untuk perhitungan Euclidean Distance Centroid 2, dan Euclidean Distance Centroid 3 dilakukan seperti pada tabel 4 namun berdasarkan nilai centroid masingmasing pada tabel 3 . 
PETIR: Jurnal Pengkajian dan Penerapan Teknik Informatika Vol. 13, No. 1, Maret 2020, P-ISSN 1978-9262, E-ISSN 2655-5018 DOI: https://doi.org/10.33322/petir.v13i1.925

3. Menentukan Pengelompokan Berdasarkan Hasil Euclidean Distance

Tabel 5. Penentuan Cluster Loop-1 Time In Hospital

\begin{tabular}{|c|c|c|c|c|c|}
\hline \multicolumn{6}{|c|}{ Loop - 1 Time In Hospital } \\
\hline ED-1* & ED-2* & ED-3* & Cluster 1 & Cluster 2 & Cluster 3 \\
\hline 0 & 13 & 7 & 1 & - & - \\
\hline 2 & 11 & 5 & 1 & - & - \\
\hline 13 & 0 & 6 & - & 1 & - \\
\hline 1 & 12 & 6 & 1 & - & - \\
\hline 13 & 0 & 6 & - & 1 & - \\
\hline 8 & 5 & 1 & - & - & 1 \\
\hline 12 & 1 & 5 & - & 1 & - \\
\hline 4 & 9 & 3 & - & - & 1 \\
\hline 7 & 6 & 0 & - & - & 1 \\
\hline 13 & 0 & 6 & - & 1 & - \\
\hline \multicolumn{6}{|c|}{$\begin{array}{l}\text { * Note: } \\
\text { - ED adalah Euclidean Distance. Dan nilai Euclidean Distance ini merupakan nilai yang telah dihitung } \\
\text { sebelumnya } \\
\text { - Angka } 1 \text { pada Cluster 1, Cluster 2, Cluster } 3 \text { merupakan tanda bahwa data dikelompokkan pada } \\
\text { cluster. }\end{array}$} \\
\hline
\end{tabular}

Dalam penentuan cluster dilakukan berdasarkan nilai dari Euclidean Distance yang telah di hitung sebelumnya pada tabel 4 . Untuk penentuannya, dari tiap baris tersebut yang memiliki nilai Euclidean Distance terendah maka akan menjadi cluster dari kelompok Euclidean Distance tersebut. Adapun contoh pada tabel 5 untuk Cluster Loop-1 Time In Hospital.

4. Menetukan Pengelompokan Nilai Atribut Time In Hospital

Tabel 6. Hasil Cluster Loop-1 Time In Hospital

\begin{tabular}{|c|c|c|}
\hline No. & time_in_hospital & Cluster Loop-1 \\
\hline 1 & 1 & Cluster 1 \\
\hline 2 & 3 & Cluster 1 \\
\hline 3 & 14 & Cluster 2 \\
\hline 4 & 2 & Cluster 1 \\
\hline 5 & 14 & Cluster 2 \\
\hline 6 & 9 & Cluster 3 \\
\hline 7 & 13 & Cluster 2 \\
\hline 8 & 5 & Cluster 3 \\
\hline 9 & 8 & Cluster 3 \\
\hline 10 & 14 & Cluster 2 \\
\hline
\end{tabular}

Pada tabel 6 merupakan hasil dari penentuan cluster loop-1 time in hospital pada tabel 5. Dan nilai pada kolom time in hospital berdasarkan dari tabel dataset yang digunakan atribut time in hospital.

5. Menentukan Nilai Centroid Baru

Tabel 7. Nilai Centroid Loop-2 Time In Hospital

\begin{tabular}{|c|c|c|c|}
\hline Perulangan & Nama Centroid & Perhitungan & Nilai Centroid \\
\hline \multirow{3}{*}{ Loop -2} & Centroid 1 & $(1+3+2) / 3$ & 2 \\
\cline { 2 - 4 } & Centroid 2 & $(14+14+13+14) / 4$ & 13.75 \\
\cline { 2 - 4 } & Centroid 3 & $(9+5+8) / 3$ & 7.333333333 \\
\hline
\end{tabular}


PETIR: Jurnal Pengkajian dan Penerapan Teknik Informatika Vol. 13, No. 1, Maret 2020, P-ISSN 1978-9262, E-ISSN 2655-5018 DOI: https://doi.org/10.33322/petir.v13i1.925

Pada tabel 7 merupakan penentuan nilai centroid loop-2 atribut time in hospital yang dimana nilai perhitungan berdasarkan hasil pengelompokan dari tabel 6 dan menggunakan rumus 2 . Kolom nilai centroid merupakan hasil dari perhitungan dari kolom perhitungan.

Jika Nilai setiap centroid baru sama dengan nilai setiap centroid sebelumnya, maka proses $K$-Means selesai. Jika tidak ulangi proses dari langkah ke 2 yaitu perhitungan Euclidean Distance setiap centroid menggunakan nilai centroid baru.

Langkah 1-5 diatas juga dilakukan untuk menentukan pengelompokan pada atribut num lab procedures, num procedures, dan num diagnoses. Setelah dikelompokan pada proses $K$-Means. Hasil pengelompokan akan digunakan untuk proses $C 4.5$.

B. Proses $C 4.5$

Pada proses $C 4.5$ pertama tentukan atribut mana yang akan diprediksi. Dalam kasus ini atribut yang akan diprediksi adalah AlcResult. Untuk atribut yang akan diprediksi dilakukan perhitungan entropy pada tabel 8 .

Tabel 8. Nilai Entropy AlcResult

\begin{tabular}{|c|c|c|c|}
\hline Jenis Nilai & Jumlah & Perhitungan Entropy & Entropy \\
\hline Norm & 4 & $\left(\frac{4}{10} \times(-1)\right) \times \log _{2}\left(\frac{4}{10}\right)$ & 0.528771238 \\
\hline$>7$ & 3 & $\left(\frac{3}{10} \times(-1)\right) \times \log _{2}\left(\frac{3}{10}\right)$ & 0.521089678 \\
\hline$>8$ & 3 & $\left(\frac{3}{10} \times(-1)\right) \times \log _{2}\left(\frac{3}{10}\right)$ & 0.521089678 \\
\hline Total Data & 10 & Total Entropy (AlcResult) & 1.570950594 \\
\hline
\end{tabular}

Setelah didapatkan nilai entropy AlcResult berdasarkan rumus 3, maka tahap selanjutnya hitunglah nilai entropy dan gain tiap atribut lainnya. Dalam perhitungan nilai gain tiap atribut lainnya akan bersangkutan dengan nilai total entropy AlcResult, yang dimana nilai entropy AlcResult akan digunakan dalam hitung gain total tiap atribut. Adapun contoh perhitungan entropy pada atribut gender.

Tabel 9. Nilai Entropy Gender

\begin{tabular}{|c|c|c|c|c|c|}
\hline \multicolumn{2}{|c|}{ Jenis Nilai } & \multirow{2}{*}{$\begin{array}{c}\text { Jumlah } \\
1\end{array}$} & \multicolumn{2}{|c|}{ Perhitungan Entropy } & \multirow{2}{*}{$\begin{array}{c}\text { Entropy } \\
0.464385619\end{array}$} \\
\hline \multirow{3}{*}{ 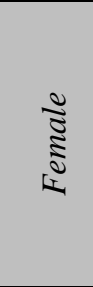 } & Norm & & $\left(\frac{1}{5} \times(-1)\right)$ & $\times \log _{2}\left(\frac{1}{5}\right)$ & \\
\hline & $>7$ & 2 & $\left(\frac{2}{5} \times(-1)\right)$ & $\times \log _{2}\left(\frac{2}{5}\right)$ & 0.528771238 \\
\hline & $>8$ & 2 & $\left(\frac{2}{5} \times(-1)\right)$ & $\times \log _{2}\left(\frac{2}{5}\right)$ & 0.528771238 \\
\hline \multicolumn{2}{|c|}{ Total Data (Female) } & 5 & \multicolumn{2}{|c|}{ Total Entropy (Female) } & 1.521928095 \\
\hline \multirow{3}{*}{$\frac{\mathfrak{z}}{\mathfrak{z}}$} & Norm & 3 & $\left(\frac{3}{5} \times(-1)\right)$ & $\times \log _{2}\left(\frac{3}{5}\right)$ & 0.442179356 \\
\hline & $>7$ & 1 & $\left(\frac{1}{5} \times(-1)\right)$ & $\times \log _{2}\left(\frac{1}{5}\right)$ & 0.464385619 \\
\hline & $>8$ & 1 & $\left(\frac{1}{5} \times(-1)\right)$ & $\times \log _{2}\left(\frac{1}{5}\right)$ & 0.464385619 \\
\hline \multicolumn{2}{|c|}{ Total Data (Male) } & 5 & \multicolumn{2}{|c|}{ Total Entropy (Male) } & 1.370950594 \\
\hline
\end{tabular}


PETIR: Jurnal Pengkajian dan Penerapan Teknik Informatika

Pada tabel 9 dilakukan perhitungan nilai entropy pada tiap jenis nilai yang terdapat pada atribut gender. Pada kolom jumlah, merupakan jumlah data yang dikelompokkan berdasarkan tiap jenis atribut gender yang memiliki nilai norm, $>7$, dan $>8$ pada atribut Alcresult. Perhitungan ini berdasarkan dari data hasil $K$-Means dan menggunakan rumus 3. Hasil nilai pada kolom entropy berdasarkan perhitungan dari kolom perhitungan entropy. Dan total entropy merupakan total dari nilai entropy tiap jenis nilai pada atribut gender.

Tabel 10. Nilai Gain Atribut Gender

\begin{tabular}{|c|c|}
\hline Perhitungan & Total Gain Gender \\
\hline $1.570950594-\left(\left(\frac{5}{10} \times 1.521928095\right)+\left(\frac{5}{10} \times 1.370950594\right)\right)$ & 0.12451125 \\
\hline
\end{tabular}

Pada tabel 10 merupakan perhitungan dan hasil nilai gain pada atribut gender. Perhitungan yang dilakukan pada tabel 10 menggunakan nilai total entropy atribut Alcresult pada tabel 8 dan menggunakan total data dan total entropy tiap jenis nilai pada atribut gender pada tabel 9 dan menggunakan rumus 4. Kolom total gain gender merupakan hasil dari perhitungan pada kolom perhitungan tabel 10.

Setelah dilakukan perhitungan entropy dan gain pada setiap atribut. Dari nilai gain semua atribut kecuali Alcresult carilah nilai gain yang tertinggi. Nilai gain tertinggi akan menjadi root pada pohon keputusan (Decision Tree). Pada kasus ini nilai gain tertinggi adalah atribut Diagnosis 1.

Tabel 11. Root Decision

\begin{tabular}{|c|c|c|c|c|c|}
\hline \multirow{3}{*}{ Nama Atribut } & \multicolumn{4}{|c|}{ Jenis Nilai } & \multirow{2}{*}{ Jumlah } \\
\cline { 2 - 6 } & Diagnosis 1 & Norm & $>7$ & $>8$ & \\
\hline \multirow{5}{*}{ Diagnosis 1 } & 411 & 1 & 0 & 0 & 1 \\
\cline { 2 - 6 } & 427 & 1 & 0 & 0 & 1 \\
\cline { 2 - 6 } & 434 & 1 & 0 & 0 & 1 \\
\cline { 2 - 6 } & 250.13 & 1 & 0 & 0 & 1 \\
\cline { 2 - 6 } & V57 & 0 & 0 & 1 & 1 \\
\cline { 2 - 6 } & 276 & 0 & 0 & 1 & 1 \\
\cline { 2 - 6 } & 998 & 0 & 0 & 1 & 1 \\
\cline { 2 - 6 } & 584 & 0 & 1 & 0 & 1 \\
\cline { 2 - 6 } & 410 & 0 & 1 & 0 & 1 \\
\cline { 2 - 6 } & 295 & 0 & 1 & 0 & 1 \\
\hline
\end{tabular}

Pada tabel 11, bagian jenis nilai Diagnosis 1 digunakan untuk menjadi leaf tree. Untuk hasil keputusan tiap leaf tree berdasarkan jumlah jenis nilai Norm, $>7$, dan $>8$ dari tiap jenis nilai Diagnosis 1. Jika tiap jenis nilai Diagnosis 1 hanya memiliki satu jenis jumlah dari nilai Norm, $>7$, dan $>8$. Maka hasil keputusan pada leaf tree akan mengikuti nilai tersebut. Contoh jenis nilai Diagnosis 1 yaitu 411 hanya memiliki jumlah jenis nilai pada nilai Norm, sedangkan $>7$ dan $>8$ berjumlah 0 . Maka hasil keputusan pada nilai 411 adalah Norm. Jika tiap jenis nilai atribut memiliki jumlah nilai selain salah satu dari Norm, $>7$, dan >8. Maka hasil pada leaf tree pada jenis nilai atribut tersebut harus ditentukan dengan mengulangi kembali semua langkah dari awal C4.5 kecuali atribut yang telah menjadi tree tidak perlu dihitung kembali. Pada modeling ini, hasil dari tiap nilai jenis atribut Diagnosis 1 menunjukkan hanya memiliki 1 nilai dari 3 jenis nilai AlcResult. 
PETIR: Jurnal Pengkajian dan Penerapan Teknik Informatika

Sehingga perhitungan selesai dan tidak perlu melakukan perulangan. Adapun hasil decision tree sebagai berikut (gambar 7):

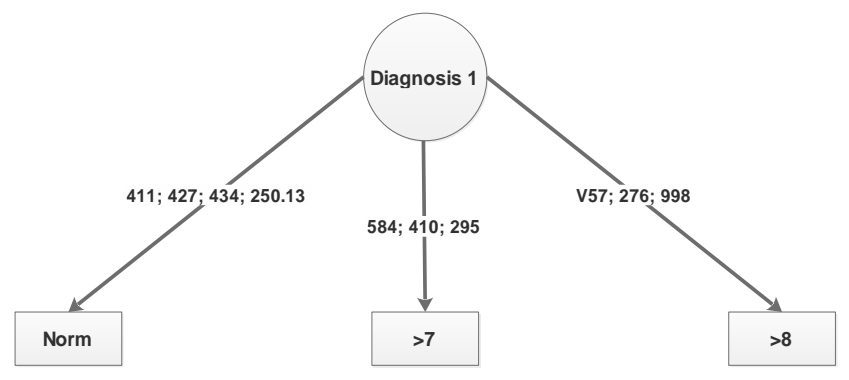

Gambar 7. Decision Tree C4.5

\subsection{Evaluation}

Mengevaluasi model dan hasil yang dilakukan pada tahap modeling. Adapun hasilnya dalam kasus ini adalah jumlah data yang digunakan akan mempengaruhi mempengaruhi bentuk decision tree. Dalam kasus ini menggunakan 10 data sebagai sample.

\subsection{Deployment}

Menerapkan hasil dari model yang didapatkan dari tahapan modeling. Adapun implementasi diterapkan pada pembuatan aplikasi untuk memprediksi HbAlc dan didalam aplikasi tersebut terdapat pengimplementasian metode $K$-Means dan C4.5.

\subsection{Validasi Akurasi}

Validasi akurasi bukan merupakan tahapan CRISP-DM. Tahapan ini akan menguji validasi tingkat keakurasian hasil prediksi HbA1c terhadap metode $K$-Means dan $C 4.5$. Dalam pengujian validasi akurasi menggunakan $K$-Fold Cross Validation. Adapun rumus $K$-Fold Cross Validation sebagai berikut rumus (5) [11]:

$$
\text { akurasi }=\frac{\sum \text { klasifikasi benar }}{\sum \text { data uji }} \times 100 \%
$$

Keterangan:

akurasi= hasil akurasi

klasifikasi benar $=$ jumlah prediksi benar

data uji = jumlah data yang dilakukan pengujian

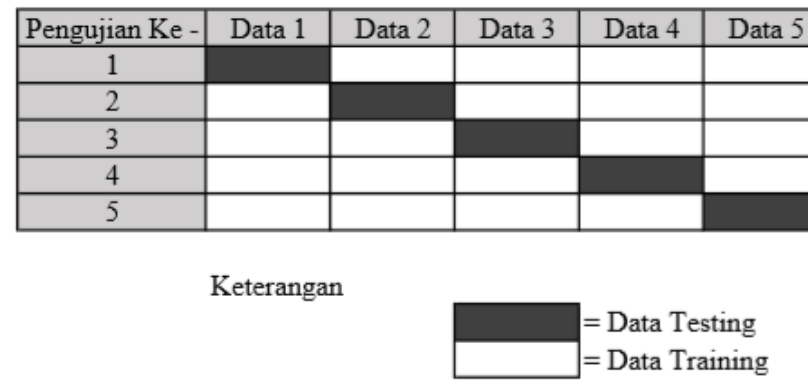

Gambar 8. Pembagian Data Training dan Data Testing

Pada gambar 6 merupakan pembagian data training dan data testing pada tiap skema pengujian. Yang dimana pada kasus ini setiap kelompok data terdapat 5 jumlah data didalamnya. 
PETIR: Jurnal Pengkajian dan Penerapan Teknik Informatika Vol. 13, No. 1, Maret 2020, P-ISSN 1978-9262, E-ISSN 2655-5018

Tabel 12. Perhitungan Akurasi K-Fold Cross Validation

\begin{tabular}{|c|c|c|c|c|}
\hline Pengujian Ke & $\begin{array}{l}\text { Jumlah Prediksi } \\
\text { Benar }\end{array}$ & $\begin{array}{l}\text { Jumlah Prediksi } \\
\text { Salah }\end{array}$ & Perhitungan & Akurasi \\
\hline 1 & 2 & 3 & \multirow{5}{*}{$\frac{(2+4+4+4+4)}{25}(\times 100 \%)$} & \multirow{5}{*}{$72 \%$} \\
\hline 2 & 4 & $\mathbf{1}$ & & \\
\hline 3 & 4 & 1 & & \\
\hline 4 & 4 & 1 & & \\
\hline 5 & 4 & 1 & & \\
\hline
\end{tabular}

Tabel 12 merupakan perhitungan akurasi K-Fold Cross Validation yang dimana nilai pada kolom jumlah prediksi benar dan jumlah prediksi salah berdasarkan data pada skema gambar 5. Dan pada tabel 12 menggunakan rumus 5 . Kolom akurasi pada tabel 12 merupakan hasil perhitungan dari kolom perhitungan.

\section{HASIL DAN PEMBAHASAN}

\subsection{Perbandingan Hasil}

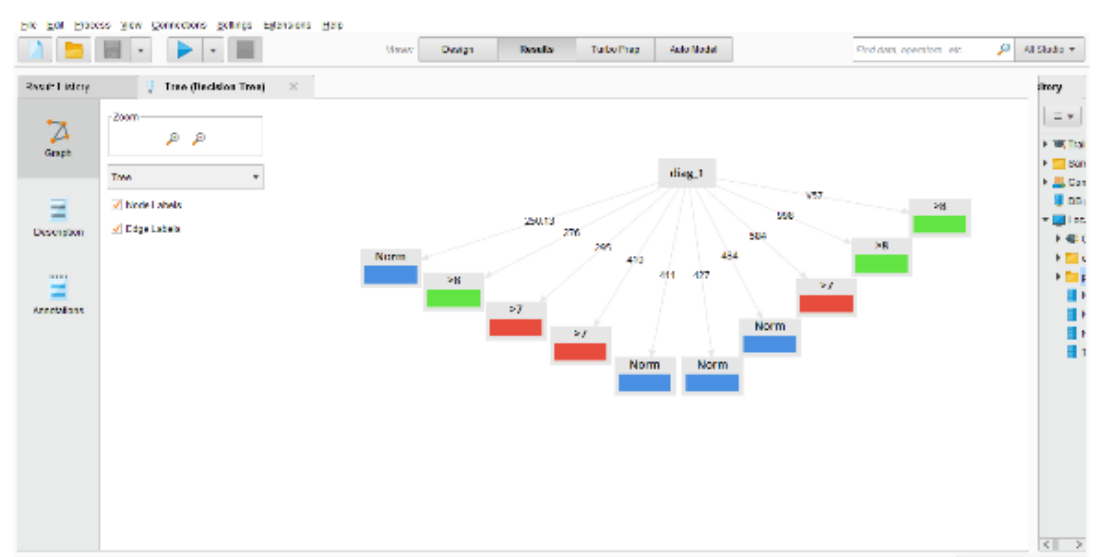

Gambar 9. Rapidminer Hasil Decision Tree C4.5

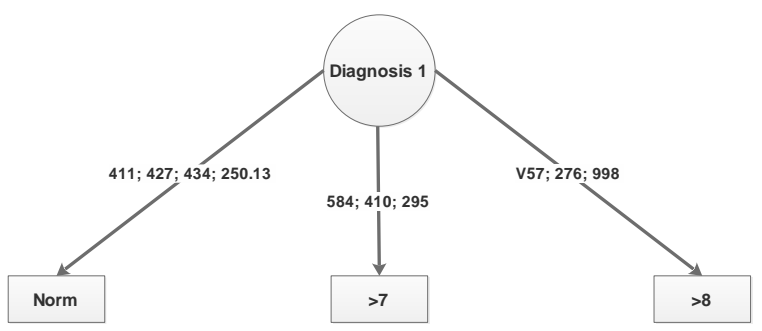

Gambar 10. Microsoft Excel Hasil Decision Tree C4.5 
PETIR: Jurnal Pengkajian dan Penerapan Teknik Informatika

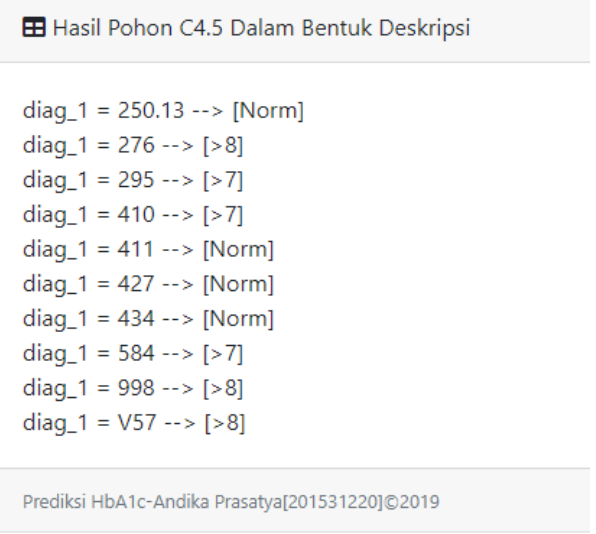

Gambar 11. Aplikasi Hasil Decision Tree C4.5

Dari hasil pada gambar 7, 8, dan 9. Didapatkan kesimpulan bahwa hasil decision tree C4.5 pada rapidminer, microsoft excel, dan aplikasi adalah memiliki hasil yang sama. Pada hasil decision tree C4.5 didapatkan bahwa atribut yang menjadi root adalah atribut diagnosis 1. Hasil yang didapatkan dari setiap decision tree pada rapidminer, microsoft excel, dan aplikasi yang proses dari $K$-Means hingga $C 4.5$ berdasarkan dari tiap-tiap tools tersebut.

\subsection{Implikasi}

Dari hasil penelitian yang didapatkan bahwa data pasien penderita diabetes pada penelitian ini dapat digunakan pada metode $K$-Means dan C4.5. Dikarenakan dari penelitian dengan menggunakan metode $K$-Means dan $C 4.5$ pada data penderita diabetes didapatkan hasil prediksi dan akurasi. Akurasi hasil validasi menggunakan K-Fold Cross Validation sebesar $72 \%$. Berdasarkan hasil akurasi yang didapatkan tersebut, maka prediksi $H b A l c$ dapat digunakan sebagai salah satu solusi untuk mengatasi keterbatasan laboratorium dalam memberikan pelayanan pemeriksaan $H b A l c$ pada penderita diabetes.

\section{KESIMPULAN DAN SARAN}

\subsection{Kesimpulan}

Hasil penelitian ini dapat digunakan sebagai salah satu solusi untuk mengatasi keterbatasan pada laboratorium dalam memberikan alternatif keputusan pelayanan pemeriksaan HbA1c pada penderita diabetes yang akan melakukan kontrol / konsultasi ke dokter. Namun adapun ketentuan atau syarat supaya hasil penelitian ini dapat dijadikan solusi yaitu dalam proses training pada metode $K$-Means dan $C 4.5$ yang digunakan untuk menentukan pola atau rule prediksi HbA1c diharuskan menggunakan data training yang banyak, bervariasi, dan terdapat unsur unik pada data tersebut. Jika tidak memenuhi ketentuan tersebut maka yang terjadi ketika ingin memprediksi HbAlc pada penderita diabetes yang dimana data penderita tersebut nilainya tidak ada dalam pola atau rule maka hasil prediksi HbAlc yang didapatkan memiliki tingkat keakurasian yang rendah dan bahkan juga hasil yang didapatkan adalah tidak diketahui.

Dan juga hasil akurasi validasi yang didapatkan dengan $K$-Fold Cross Validation terdapat pada tabel 12 sebesar $72 \%$

\subsection{Saran}

Pengembangan kedepannya dapat menggunakan metode yang berbeda dari metode pada penelitian ini sehingga dapat dibandingkan. Dari perbandingan tersebut akan menghasilkan kesimpulan metode mana yang menghasilkan akurasi prediksi $H b A l c$ yang terbaik. 


\section{DAFTAR PUSTAKA}

[1] C. Buell, D. Kermah, and M. B. Davidson, "Utility of A1C for Diabetes Screening in the 1999 2004 NHANES Population,” Diabetes Care, vol. 30, no. 9, pp. 2233-2235, Sep. 2007.

[2] S. R. Paputungan and H. Sanusi, "Peranan Pemeriksaan Hemoglobin A1c pada Pengelolaan Diabetes Melitus," Cdk-220, vol. 41, no. 9, pp. 650-655, 2014.

[3] S. Bahri, D. M. Midyanti, and R. Hidayati, "Perbandingan Algoritma Naive Bayes dan C4 . 5 Untuk Klasifikasi Penyakit Anak,” Semin. Nas. Apl. Teknol. Inf., vol. 07, no. 22, pp. 24-31, 2018.

[4] L. Zahrotun, "Analisis Pengelompokan Jumlah Penumpang Bus Trans Jogja Menggunakan Metode Clustering K-Means Dan Agglomerative Hierarchical Clustering (AHC), J. Inform., vol. 9, no. 1, pp. 1039-1047, Jan. 2015.

[5] V. Derbentsev, N. Datsenko, O. Stepanenko, and V. Bezkorovainyi, "Forecasting Cryptocurrency Prices Time Series Using Machine Learning Approach,” SHS Web Conf., vol. 65, p. 02001, May 2019.

[6] S. A. Soelistijo et al., Konsensus Pengelolaan Dan Pencegahan Diabetes Melitus Tipe 2 Di Indonesia 2015, no. 11. PB. PERKENI, 2015.

[7] B. Strack et al., "Impact of HbA1c measurement on hospital readmission rates: Analysis of 70,000 clinical database patient records," Biomed Res. Int., vol. 2014, 2014.

[8] M. Nishom and D. S. Wibowo, "Implementasi Metode K-Means berbasis Chi-Square pada Sistem Pendukung Keputusan untuk Identifikasi Disparitas Kebutuhan Guru," J. Sist. Inf. Bisnis, vol. 8, no. 2, p. 187, Nov. 2018.

[9] M. Mirqotussa'adah, M. A. Muslim, E. Sugiharti, B. Prasetiyo, and S. Alimah, "Penerapan Dizcretization dan Teknik Bagging Untuk Meningkatkan Akurasi Klasifikasi Berbasis Ensemble pada Algoritma C4.5 dalam Mendiagnosa Diabetes," Lontar Komput. J. Ilm. Teknol. Inf., no. September, p. 135, Aug. 2017.

[10] A. Paramitha Fadillah, "Penerapan Metode CRISP-DM untuk Prediksi Kelulusan Studi Mahasiswa Menempuh Mata Kuliah (Studi Kasus Universitas XYZ),” JuTISI, vol. 1, pp. 260 270, Apr. 2015.

[11] F. Tempola, M. Muhammad, and A. Khairan, "Perbandingan Klasifikasi Antara KNN dan Naive Bayes pada Penentuan Status Gunung Berapi dengan K-Fold Cross Validation,” J. Teknol. Inf. dan Ilmu Komput., vol. 5, no. 5, p. 577, Oct. 2018.

[12] Budiana ND, Siregar RR, Susanti MN. Penetapan Instruktur Diklat Menggunakan Metode Clustering K-Means dan Topsis Pada PT PLN (Persero) Udiklat Jakarta. PETIR: Jurnal Pengkajian dan Penerapan Teknik Informatika. 2019 Aug 6;12(2):111-21.

[13] Siregar RR, Nasution FS. Algoritma C4. 5 Untuk Prediksi Tingkat Kelulusan Mahasiswa Jurusan Teknik Informatika STT PLN. Jurnal Informatika dan Komputasi. 2017 Mar 1;9(1):16.

[14] Setiyadi D. Data Mining Dengan Metode Decision Tree Algoritma C4. 5 Untuk Memprediksi Permintaan Jenis Produk Barang. Inesit 2019 Apr 30 (Vol. 6, No. 2, Pp. 13-34).

[15] Patel HG, Sarvakar K. Research Challenges and Comparative Study of Various Classification Technique Using Data Mining. International Journal of Latest Technology in Engineering, Management \& Applied Science. 2014;3(9):170-6. 